\title{
Doing Good with Data: Development of a Maturity Model for Data Literacy in Non-governmental Organizations
}

\author{
Helena Sternkopf \\ Berlin School of Economics and Law \\ sternkopf.h@gmail.com
}

\author{
Roland M. Mueller \\ Berlin School of Economics and Law \\ roland.mueller@hwr-berlin.de
}

\begin{abstract}
Data literacy is the ability to use data productively and to think about it in a critically reflective way. However, can its complexity really be broken down to only this? Data literacy is one of the most important skills in the 21 st century for organizations, employees, and citizens. We present a data literacy maturity model (DLMM) that was developed in the context of non-governmental organizations (NGOs). Based on the development of a preliminary maturity model, action design research $(A D R)$ is used to develop the model throughout three iteration phases. The main contribution is a data literacy maturity grid that describes 11 data literacy competencies on four competence levels that is complemented by a self-assessment tool. The proposed maturity model should enhance the understanding of the required skills that are needed to kick off data projects, identify strengths and gaps, and thus empower to plan future data practices in accordance with predefined goals.
\end{abstract}

Keywords: Data Literacy, Maturity Model, NGO, Action Design Research, Social Change

\section{Introduction}

Data literacy is "the ability to consume for knowledge, produce coherently, and think critically about data" [20:122]. It describes a set of skills that are becoming more and more important for companies, nonprofit organizations, and citizens as new data streams emerge from various new sources, such as mobile phones, credit cards, televisions, city infrastructure, sensor-equipped buses, trains, and buildings. This far surpasses any prior data record of human civilization [31]. However, it is not only the revolutionary amount of data that is collected, but also the growing sophistication of statistical and computational methods [24] that requires a shift in the required skills for the data era [10].

The motive for improving data literacy seems unequivocal. Still, large parts of our society do not have much clarity about what data literacy means and what can be expected from it [10, 39]. NGOs and their employees still lag behind data practitioners in the scientific and business environment [14]. Therefore, there is still a large gap between the potential of data literacy and its actual use in progressing societal change due to missing resources, capability, or opportunity $[14,35]$. Due to this research gap, this paper focuses on investigating possible data literacy practices for social change organizations apart from business and science. Bhargava and D'Ignazio [3] argue that there is "a lack of consistent and appropriate approaches for helping novices learn to "speak data." Hence, it is essential to find a way to describe data-handling and data-conversion skills and to translate them for an audience of different backgrounds and competencies. One possibility for translating, representing, and assessing capabilities on different levels is the use of maturity models [2, 24, 28].

Hence, the central research question of this study is:

$R Q:$ How can we describe data literacy in a maturity model for evaluating individuals' data-handling capabilities in the context of $\mathrm{NGOs?}$

\section{Related Literature}

\subsection{Data Literacy}

Key principles of data literacy have their roots in diverse areas, such as mathematics, data mining, statistics, graphic design, and information visualization [4, 18]. Even though the term data literacy is increasingly used in the recent discourse on "datafication" $[10,35]$, the meaning of the term remains ambiguous $[3,4,10,20]$. 
To overcome this ambiguity when describing data literacy, we start by looking at the two words that it comprises. Data can be understood as signals, in their raw form, that represent ideas or objects. It can be input, processed by computational applications, and output as information. Data can be distinguished as structured or unstructured data. Felden [16] defines structured data as objects that are machine-readable and unstructured data as items that are not easily machine-readable.

Literacy has proven to be a complex and dynamic concept, which is still interpreted in various ways [36]. Researchers from UNESCO [36:13] define literacy as "the ability to identify, understand, interpret, create, communicate and compute, using printed and written materials associated with varying contexts. Literacy involves a continuum of learning in enabling individuals to achieve their goals, to develop their knowledge and potential, and to participate fully in their community and wider society."

Combining the two terms and formulating a definition of data literacy leaves us with a description that could read as follows:

Data literacy is a continuous learning journey that creates the ability to identify, understand, interpret, create, communicate, and compute pieces of information (data) to develop knowledge and the ability to participate fully in our society.

This definition is, in fact, not too distant from the definitions we find in literature. Researchers who have investigated the field of data literacy, such as Calzada Prado and Marzal [4], argue that "the identification of the competencies needed to be data literate is a matter presently under study by a fairly large community of researchers [...] in different domains," highlighting that these investigations are all subject to the research context and purpose, which makes the topic all the more ambiguous. All data literacy definitions that are reviewed in the following are based on specific contexts; this illustrates the importance of data literacy in many areas but also limits the ability to find one common definition (see Table 1). The reviewed literature has been analyzed in accordance with the concept-centric literature review as described by Webster and Watson [38].

Despite certain overlaps, the definitions differ from each other and vary in their preciseness. The theoretical base for designing a preliminary maturity model will be provided by Slater [32] since it is one of the most recent ones and is closely connected to our study object, the Datenschule. This choice is taken to fully profit from exploratory research within the expert interviews. The initial design will only include seven dimensions. Throughout the iteration loops, the model will gradually evolve, and the dimensions will be identified with the help of the expert interviews, as well as their respective cell descriptions.

Table 1. Existing data literacy definitions

\begin{tabular}{|c|c|c|}
\hline Author(s) & Focus & Data Literacy Properties \\
\hline $\begin{array}{l}\text { [4] Calzada } \\
\text { Prado, J., and } \\
\text { Marzal, M.Á. } \\
\text { (2013) }\end{array}$ & $\begin{array}{l}\text { Librarian } \\
\text { Data Literacy }\end{array}$ & $\begin{array}{l}\text { - Understand } \\
\text { - Find and/or obtain } \\
\text { - Read } \\
\text { - Interpret } \\
\text { - Evaluate } \\
\text { - Manage } \\
\text { - Use }\end{array}$ \\
\hline $\begin{array}{l}\text { [12] Deahl, E. } \\
\text { (2014) }\end{array}$ & $\begin{array}{l}\text { School Data } \\
\text { Literacy }\end{array}$ & $\begin{array}{l}\text { - Understand } \\
\text { - Find } \\
\text { - Collect } \\
\text { - Interpret } \\
\text { - Visualize } \\
\text { - Support arguments }\end{array}$ \\
\hline $\begin{array}{l}\text { [3] Bhargava, } \\
\text { R., and } \\
\text { D’Ignazio, C. } \\
(2015)\end{array}$ & $\begin{array}{l}\text { Data Literacy } \\
\text { Tool Design }\end{array}$ & $\begin{array}{l}\text { - Read } \\
\text { - Work with } \\
\text { - Analyze } \\
\text { - Argue }\end{array}$ \\
\hline $\begin{array}{l}{[39] \text { Wolff, A., }} \\
\text { Gooch, D., } \\
\text { Cavero } \\
\text { Montaner, J. J., } \\
\text { Rashid, U. and } \\
\text { Kortuem, G. } \\
(2016)\end{array}$ & $\begin{array}{l}\text { Community } \\
\text { Data Literacy }\end{array}$ & $\begin{array}{l}\text { - Ask and answer questions } \\
\text { - Ethical use of data } \\
\text { - Select } \\
\text { - Clean } \\
\text { - Analyze } \\
\text { - Visualize } \\
\text { - Critique and interpret } \\
\text { - Communicate stories }\end{array}$ \\
\hline $\begin{array}{l}\text { [32] Slater, D. } \\
(2016)\end{array}$ & $\begin{array}{l}\text { Data } \\
\text { Journalism }\end{array}$ & $\begin{array}{l}\text { - Find } \\
\text { - Apply critical thinking } \\
\text { - Ask questions } \\
\text { - Create outputs } \\
\text { - Advance goals } \\
\text { - Feel comfortable to work } \\
\text { with data } \\
\text { - Statistical analysis }\end{array}$ \\
\hline
\end{tabular}

\subsection{Maturity Approaches}

Traditionally, measuring capabilities is complex, but it can help an organization to reach its objectives [7] since it can support various areas in an organization, including decision-making, motivating employees, and stimulating learning, as well as improving communication and strategic planning [23]. One approach to assessing organizational capabilities and stimulating improvement is by means of maturity models [28]. The basic concept of all maturity models is based on the fact that things change over time and that these changes can be predicted and regulated to a certain extent [29]. 
Maturity depicts that someone or something has arrived at a state of plentitude and readiness [5]. Based on the presumption of anticipated patterns, maturity models illustrate how organizational capabilities evolve in a stage-by-stage manner along a plausible maturation path $[15,19,37]$. Essentially, maturity models briefly describe prevalent behavior of an entity at different levels of maturity, for several elements of the area under study. This study concentrates on the process of how to define data literacy and its path to maturity, through considering different levels and dimensions. Knowing which elements to alter can thus help organizations move to their desired level in the respective area [24]. Nevertheless, the top level need not necessarily be the most desirable one to reach, but it has to be evaluated in close consideration of specific organizational contexts and individual objectives [24, 29]. That being said, there are also different purposes of maturity models that can be distinguished: descriptive, prescriptive, and comparative $[2,24]$. This paper describes the development of a descriptive maturity model.

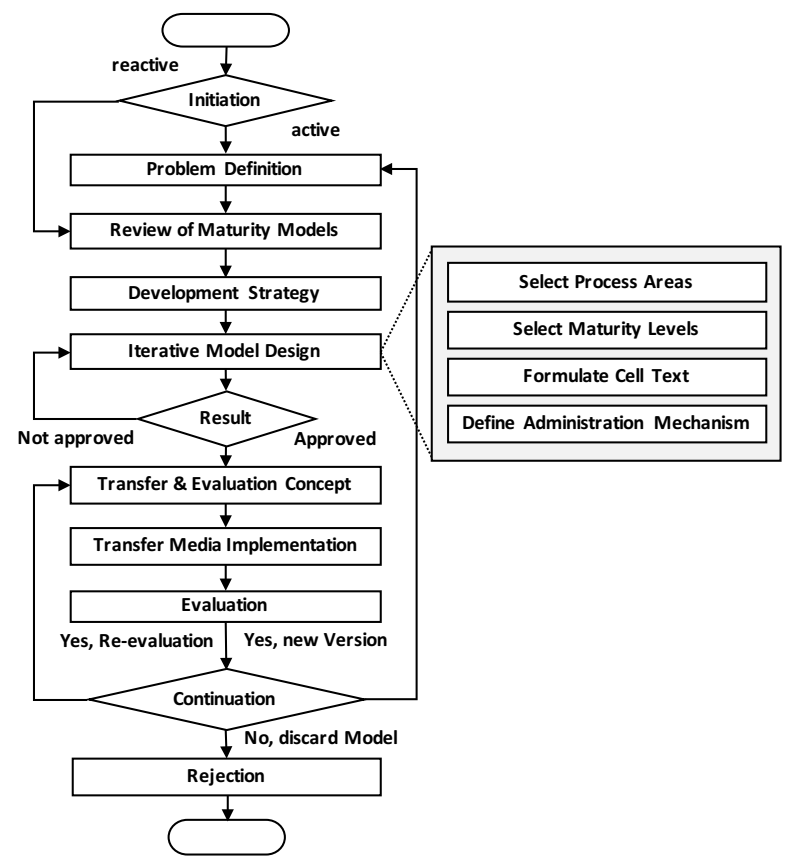

Figure 1. Maturity model development procedure $[2,23]$

The development of the DLMM will follow a combination of two procedure models that have been developed by Becker et al. [2] and Maier et al. [24] to cover all necessary aspects of the maturity model design and to guarantee a clear development structure (see Figure 1).

\section{Research Method}

Generally, the development of maturity frameworks can be considered as design science research [2]. Becker et al. [2:214] note that "maturity models can be understood as artifacts which serve to solve the problems of determining a company's status quo of its capabilities and deriving measures for improvement therefrom." This fits the principles of design science, which aim at improving problemsolving capacities through the creation of artifacts, such as models or methods [21]. The research method of this paper is action design research (ADR) [30]. In particular, the crucial intersection of people, organizations, and technology led to the decision to combine design science [21] with action research to further highlight the applied character of the designed artifact. In order to answer the research question of how to design a maturity model for defining different levels of data literacy in NGOs, the collection of data is divided into three iteration phases and is based on an ADR schema by Sein et al. [30] (an adapted version can be seen in Figure 2).

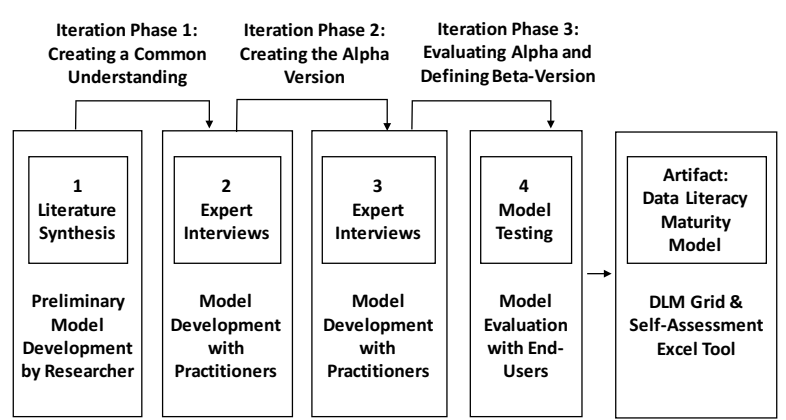

Figure 2. Applied action design research and iteration loops

The data collection is based on the Datenschule (German for "School of Data"), a project of the Open Knowledge Foundation Germany, which is based in Berlin. The Datenschule is an educational program closely related to the topic of data-handling skills. Under the slogan "Do Good with Data," the program is especially targeted to nonprofit organizations. The mission is to convey practical data knowledge to support NGOs in progressing their data practice [11]. In addition to data experts of the Datenschule, two external data scientists and researchers have been included in the development to allow for a more differentiated database.

Initially, a preliminary framework for data literacy maturity was developed by a structured literature review (Preparation Phase). This model incorporates various elements of data literacy that can be derived from relevant literature and started with 
seven capability dimensions to assess. After that, the preparatory model was reviewed by two data practitioners of the Datenschule in semi-structured expert interviews, for an initial exploration of a mutual understanding of the model as well as potential adaptations regarding their application context (Iteration Phase 1).

Second, the adapted alpha version was enriched with the help of three data practitioners who offered a more technical point of view, both Datenschuleinternal and -external, to fill the cell text of the maturity grid, as well as to identify level metrics to better distinguish among the different levels of the maturity model (Iteration Phase 2). At this point, the data collection regarding the content and conception of the maturity model was finished.

The third iteration phase was dedicated to the development of the beta version and the model evaluation in an organizational context with the end users. In this phase, the model was reviewed by two data practitioners of the Datenschule and was additionally evaluated by two representatives of an independent NGO that is currently involved in data training through testing of the questionnaire and the maturity grid. Data was collected between November 2016 and January 2017. The iterative artifact design process of ADR depicts a sample strategy based on purposeful sampling. Due to the time constraints of this study, the number of interview partners is limited to nine. This decision limits the theory developed in this paper, but it also complies with the purpose of this study to represent the first scientific exploration of the possible design of a data literacy maturity model.

This study analyzed the collected data in conformity with Meuser and Nagel [26], who established a strategy of qualitative content analysis for expert interviews to determine central, common, and typical phenomena as well as contradictions of certain aspects.

\section{Development of a Data Literacy Maturity Model}

\subsection{Problem Definition}

As described in the introduction of this paper, we accumulate more and more data, which makes it obvious that more data-handling skills are needed to use this data abundance wisely. At the same time, there is a lack of systematic definitions and procedures regarding data literacy [34]. The fact that data literacy is not a binary phenomenon that can be distinguished as literate or illiterate causes general confusion and insecurities about what to do with it and what to expect from it [10].

Hence, frameworks that try to describe data literacy need to understand, appreciate, and represent the multiplicity of it. One possible way to represent this is by means of a maturity model. While data practitioners from sciences and business are increasingly progressing in the world of data, social change organizations are still lagging behind when it comes to integrating data into their activities [14]. To close this gap, the data literacy maturity model will help to define and evaluate data-handling and dataconversion capabilities, identify strengths and weaknesses, and offer guidance for future data practices. Stakeholders of the model are nonprofit organizations that want to evaluate their data literacy capabilities or plan future actions in this field.

\subsection{Review of Existing Maturity Models}

Numerous maturity models have been derived from the generally acknowledged and recognized Quality Management Maturity Grid (QMMG) [9] and the Capability Maturity Model (CMM), which was developed for software development [27]. The origins of maturity thinking stem from quality management (QM) and Crosby's pioneering book Quality is Free [9], in which he introduces the QMMG. The QMMG advocates a simple tool that evaluates the quality management spectrum of a company in a few phrases. The QMMG recognizes that organizations can have stronger capabilities in some dimensions and weaker performance in others. Consequently, strengths and weaknesses can be easily identified, which helps to plan future actions strategically [9].

Many maturity models have been derived from Crosby's work, such as the CMM for software [27]. CMM is a model used to describe software process maturity and to which magnitude the specific process is precisely "defined, managed, measured, controlled and effective" [27:21]. Still, the CMM follows a different approach compared to the QMMG. It describes key process areas, all of which need to be completed to move on to the subsequent maturity level. This is defined as a staged approach and leads to the precise classification into one maturity level, which ranges from one to five. In Crosby's model, capabilities in the different dimensions can vary in their level of maturity, and their interdependence is not that strict.

Practitioners tend to circumvent the complexity of CMM-based maturity models by designing maturity models based on the Crosby grid approach, where performance of a number of key activities is 
described at different levels [7, 25]. Further, the grid approach as presented by Crosby follows a more organization-neutral approach and thus can be applied to a greater variety of organizations. Although maturity measurement grids tend to be less complex, they are still effective diagnostic and improvement tools [24] and will therefore create the underlying rationale of the DLMM. The need for developing a DLMM seems obvious if we look at existing maturity models in the area of data and analytics. Cosic et al. [8] present a framework for business analytics (BA) capabilities that provides a clear set of defined BA capabilities in organizations. However, it examines only the identification of these capabilities and not the differentiation of competence levels in this regard, and it examines the topic through a more organizational lens on a broader level. The DLMM aims to concentrate more on evaluating individual competences, but it will also reflect on the main capability areas identified by Cosic et al. [8], which include governance, culture, technology, and people.

\subsection{Development Strategy}

Becker et al. [2:218] suggest four basic development strategies for the design of a maturity model: "completely new model design, enhancement of an existing model, the combination of several models into a new one, and the transfer of structures or contents from existing models to new application domains." This paper combines different structures and contents from existing models to the new application domain of data literacy, which are illustrated in Table 2. Certain aspects from existing models will be combined to guarantee scientific validity while being enriched through the collection of new data.

\section{Table 2. Initial elements of the DLMM}

\begin{tabular}{|l|l|}
\hline Structure & Source \\
\hline Level Names & Chall [6], Crosby [9], Hillson [22] \\
\hline $\begin{array}{l}\text { Level } \\
\text { Descriptions }\end{array}$ & $\begin{array}{l}\text { Argyris and Schön [1], Hillson [22], } \\
\text { Debnath et al. [13] }\end{array}$ \\
\hline Dimensions & Slater [32] \\
\hline Cell Text & Slater [32] \\
\hline
\end{tabular}

\subsection{Iterative Design of the Maturity Model}

The iterative design is guaranteed through different development iteration loops. The first part concentrates on defining different components of the maturity model through insights from literature. Although various maturity models in different domains have been developed, Fraser et al. [17] identify six shared properties of most maturity models: several levels (usually three to six), descriptors for each level, generic level descriptions as a whole, several dimensions, several elements or activities for each dimension, and a description of each element/activity. The iterative development of the model is done in accordance with phase two of the procedure model as proposed by Maier et al. [24] (see Figure 1).

Select Process Areas/Dimensions. The description of relevant data literacy dimensions was initially based on the definition by Slater [32] because it is one of the most recent studies on data literacy and it is based on previous studies [3]. Throughout the development process, the model evolved from seven data literacy dimensions initially to 11 competencies to consider when evaluating data literacy in organizations both on an organizational level (1-2) and an individual level (3-11): (1) data culture, (2) data ethics and security, (3) ask questions and define, (4) find, (5) get, (6) verify, (7) clean, (8) analyze, (9) visualize, (10) communicate, and (11) assess and interpret (see Table 3 ).

Select Maturity Levels. The number of levels in a maturity model is to some extent arbitrary [17] and has to be decided based on an adequate representation of the topic under investigation. The original Crosby Quality Maturity Grid [9] used five levels, just as the software CMM [27]. The Risk Maturity Model [22] describes four levels, as does the Innovation Audit by Chiesa et al. [7]. Based on the comparison of 24 maturity models by Maier et al. [24:141-144], we see that there are usually four or five levels, which will serve as an orientation for this study.

Due to the growing complexity of an increasing number of levels, the data literacy model will be limited to four levels: (1) uncertainty, (2) enlightenment, (3) certainty, and (4) data fluency.

Formulate Cell Text. One of the major challenges when designing maturity models is the gradual description of the different levels in correspondence to the defined dimensions. In this step, levels of maturity are assigned to key aspects of performance, thereby creating a series of cells that explain the gradual performance differences. With maturation, as primary subject matter, maturity models are required to define central constructs related to maturity and maturation [2]. To obtain more clarity in this regard, it is advisable to examine the difference between immaturity and maturity. For this, an adaptation of 
the three learning types in organizations as described by Argyris and Schön [1] was used to differentiate between maturity levels and to facilitate the formulation of the cell text. A preliminary level is added to describe no or very limited engagement with the topic so far, which is missing in Argyris and Schön's considerations.

Taking a look at another general description, based on research by Hillson [22:37-38], who developed a risk maturity model, the general descriptions of the levels have been taken as an orientation for the DLMM to illustrate the overall rationale that characterizes the different levels and to add Argyris and Schön's [1] considerations.

As a further orientation for the formulation of the cell text, the underlying rationale of behaviorally anchored rating scales (BARS) is used, which is suggested by Maier et al. [24]. The BARS method is often used in human resource management to obtain a precise description of different performance levels regarding specified tasks [33]. BARS consist of a set of scales that present a major performance dimension of a particular task and are usually anchored by critical incidences that reflect highly effective to highly ineffective observable behaviors relevant to the dimension under consideration [33]. For this study, a four-level scale is applied containing the following rationale: (4) excellent performance, (3) fully competent performance, (2) marginal performance, and (1) unsatisfactory performance.

The preliminary cell text was based on the researchers' own formulations in accordance with the definitions of the selected data literacy description by Slater [32] and the theories mentioned earlier, and it was continuously enriched and adjusted through the collection of new data throughout the development process.

Define Administration Mechanism. This step includes the description of how the different dimensions will be assessed when the model is applied. In this regard, face-to-face interviews, workshops, or surveys are possible methods [24]. For the purpose of this study, the assessment will be executed through a self-evaluation tool for individuals that will refer to the maturity grid based on the results of the self-evaluation presented in a spider web diagram.

Conception of Transfer. Becker et al. [2] propose to provide different forms of results transfer for the academic and user communities. The results of this study will be made available to the academic community through the publication of the presented paper. The users will obtain the results of the maturity model development using the maturity grid as well as an Excel tool for self-evaluation provided online by the Datenschule.

Implementation of Transfer Media. The sixth phase of the development procedure proposed by Becker et al. [2] describes the implementation of the transfer media, including making the maturity model accessible to all targeted user groups. Nevertheless, the detailed implementation of the model is not within the focus of this paper.

\subsection{Evaluation}

As suggested by Becker et al. [2], evaluation criteria need to be described. In order to evaluate the model, the following success criteria, based on Pöppelbuß and Röglinger [28], are predefined: correctness, flexibility, usability, implementability, and economic efficiency. The tests were executed together with experts from the Datenschule, as well as two employees of another nonprofit organization that is currently cooperating with the Datenschule, to include an organizational perspective in the model development.

The evaluation included a test of the selfassessment questionnaire, the representation of the results, and a brief feedback interrogation. The experts evaluated the model positively. Minor changes and aspects to review were identified. In particular, the logical order and the differentiation among the different levels with the help of the selfassessment questionnaire were mentioned positively by the experts. One point for criticism was that some formulations on lower levels might be too negative and should be rephrased.

During the testing of the artifact in an organizational context together with two representatives of a partnering organization, the model was positively evaluated regarding implementability and economic efficiency. More criticism arose regarding the model's correctness, flexibility, and, to some extent, usability.

The correctness of the model was difficult to evaluate, as the representatives were not data experts and therefore were highly insecure about this aspect. On the other hand, they mentioned that a model like this might not be complete at any point, due to the complexity of the topic in general and the specific use cases in particular. Flexibility has been critically regarded, as the formulations of the possible answers in the self-assessment tool often appeared too complex and might be difficult to understand for beginners. Interestingly, the representatives had different opinions regarding usability. One testing partner mentioned that the usability is high, since the assessment tool was easy to use. 
Table 3. Data literacy maturity grid

\begin{tabular}{|c|c|c|c|}
\hline $\begin{array}{c}1 \\
\text { Uncertainty } \\
\end{array}$ & $\begin{array}{c}2 \\
\text { Enlightenment }\end{array}$ & $\begin{array}{c}3 \\
\text { Certainty } \\
\end{array}$ & $\begin{array}{c}4 \\
\text { Data Fluency } \\
\end{array}$ \\
\hline $\begin{array}{l}\text { Organizations are unaware of the } \\
\text { need for data literacy skills and } \\
\text { have no or very vague } \\
\text { understanding of what is required. } \\
\text { Individuals might have a certain } \\
\text { interest in data and work digitally, } \\
\text { but are unsure about the different } \\
\text { steps that exist when working with } \\
\text { data. }\end{array}$ & $\begin{array}{l}\text { Organizations are experimenting } \\
\text { with the application of data- } \\
\text { related topics. Describes a state } \\
\text { where a lot about data has already } \\
\text { been understood theoretically but } \\
\text { cannot be applied in many cases } \\
\text { and has to be trained further. }\end{array}$ & $\begin{array}{l}\text { Organizations perform data- } \\
\text { handling steps with confidence } \\
\text { and have data-driven activities } \\
\text { built into their routine processes } \\
\text { wherever it makes sense. Generic } \\
\text { procedures and standards on how } \\
\text { to handle data are formalized and } \\
\text { widespread, and benefits are } \\
\text { understood at all levels of the } \\
\text { organization. }\end{array}$ & $\begin{array}{l}\text { Organizations have established a } \\
\text { data-informed culture throughout } \\
\text { all levels. Data is actively used to } \\
\text { improve processes and create } \\
\text { workflows. }\end{array}$ \\
\hline \multicolumn{4}{|c|}{ Data Culture } \\
\hline $\begin{array}{l}\text { Data is perceived as an ambiguous } \\
\text { term that causes insecurities. }\end{array}$ & $\begin{array}{l}\text { Data is perceived as an interesting } \\
\text { concept, and benefits are } \\
\text { appreciated. Insecurities exist } \\
\text { regarding use cases and what } \\
\text { exactly to expect. }\end{array}$ & $\begin{array}{l}\text { Data is not perceived as a source } \\
\text { of insecurity, but rather } \\
\text { understood as an enabler for } \\
\text { progress and support for existing } \\
\text { and planned activities. Higher } \\
\text { management and leaders support } \\
\text { data initiatives. }\end{array}$ & $\begin{array}{l}\text { Psychological barriers of data have } \\
\text { been brought down (e.g., } \\
\text { insecurities, fear, resignation), and } \\
\text { comfort around data is promoted. } \\
\text { Higher-level management and } \\
\text { project managers understand and } \\
\text { support importance of dedicated } \\
\text { resources (time, budget, human } \\
\text { resources) for data handling and } \\
\text { conversion. }\end{array}$ \\
\hline \multicolumn{4}{|c|}{ Data Ethics and Security } \\
\hline $\begin{array}{l}\text { No awareness for guidelines that } \\
\text { ensure confidentiality, integrity, } \\
\text { and availability of data. }\end{array}$ & $\begin{array}{l}\text { Rising awareness and } \\
\text { uncoordinated attempts to } \\
\text { promote the importance of the } \\
\text { responsible use of data. No } \\
\text { defined guidelines. }\end{array}$ & $\begin{array}{l}\text { Awareness of the impacts of data } \\
\text { use. Guidelines for responsible } \\
\text { data handling are defined and } \\
\text { incorporated internally to } \\
\text { activities. }\end{array}$ & $\begin{array}{l}\text { Processes are in place to ensure } \\
\text { confidentiality, integrity, and } \\
\text { availability of data. Only data that } \\
\text { is necessary is collected/used. } \\
\text { Consistent, companywide policies } \\
\text { for secure and ethically sound data } \\
\text { handling are constantly redefined } \\
\text { and updated. }\end{array}$ \\
\hline \multicolumn{4}{|c|}{ Ask Question/Define } \\
\hline $\begin{array}{l}\text { Lacking ability to formulate } \\
\text { questions to find meaningful } \\
\text { answers in data. Indifference } \\
\text { about which questions can be } \\
\text { answered by data. }\end{array}$ & $\begin{array}{l}\text { Questions can be asked to data in } \\
\text { a limited number of situations, and } \\
\text { answers are provided through } \\
\text { simple queries. }\end{array}$ & $\begin{array}{l}\text { Questions to data are formulated } \\
\text { precisely and target-oriented to } \\
\text { find meaningful answers in most } \\
\text { of the cases. }\end{array}$ & $\begin{array}{l}\text { Entire projects are based on } \\
\text { multidimensional questions. } \\
\text { Answers to informational needs } \\
\text { can be found consistently in data, } \\
\text { because of the high awareness of } \\
\text { what questions can be answered by } \\
\text { data (no overinterpretation). } \\
\end{array}$ \\
\hline \multicolumn{4}{|r|}{ ( } \\
\hline $\begin{array}{l}\text { Limited understanding of possible } \\
\text { data sources. Use of basic search } \\
\text { engines to find data. No } \\
\text { experience for identifying and } \\
\text { selecting most relevant data } \\
\text { sources. }\end{array}$ & $\begin{array}{l}\text { Knowledge limited to only a few } \\
\text { data sources. Advanced use of } \\
\text { search engines. Use of internal } \\
\text { data sources and data requests at } \\
\text { public institutions are common } \\
\text { practice. }\end{array}$ & $\begin{array}{l}\text { Broad understanding of different } \\
\text { data sources, and most relevant } \\
\text { ones can be chosen from a } \\
\text { selection of data sources. } \\
\text { Awareness and use of data portals } \\
\text { for specific topics. }\end{array}$ & $\begin{array}{l}\text { Profound understanding of the } \\
\text { various possible types of data } \\
\text { sources. Assessment criteria for } \\
\text { selecting the ones most relevant to } \\
\text { an informational need are } \\
\text { formulated. Ability to detect when } \\
\text { a given problem or need cannot be } \\
\text { solved with the existing data, and } \\
\text { knowledge about research } \\
\text { techniques to obtain new data } \\
\text { (e.g., complex queries). }\end{array}$ \\
\hline \multicolumn{4}{|c|}{ Get } \\
\hline $\begin{array}{l}\text { Data is derived from full text and } \\
\text { used as base for further } \\
\text { processing. }\end{array}$ & $\begin{array}{l}\text { Use of downloads and data } \\
\text { formats such as .csv. Frequent use } \\
\text { of internal programs to access data } \\
\text { (e.g., CRM). }\end{array}$ & $\begin{array}{l}\text { Data can be accessed using more } \\
\text { complex data formats (e.g., JSON, } \\
\text { XML). Use of APIs to get data. }\end{array}$ & $\begin{array}{l}\text { Access to data through } \\
\text { sophisticated methods (e.g., } \\
\text { automated data scrapers/scripts). } \\
\text { Ability to convert input format } \\
\text { into a form that can be used for } \\
\text { further processing and analysis. }\end{array}$ \\
\hline \multicolumn{4}{|c|}{ Verify } \\
\hline $\begin{array}{l}\text { Critical evaluation of data does } \\
\text { not exist. Data is taken at face } \\
\text { value. Data evaluation criteria } \\
\text { cannot be described. }\end{array}$ & $\begin{array}{l}\text { Critical check of simple data } \\
\text { quality measures. }\end{array}$ & $\begin{array}{l}\text { Multiple layers of data checking } \\
\text { are implemented in standard } \\
\text { procedures across the } \\
\text { organization. }\end{array}$ & $\begin{array}{l}\text { Ability to do data quality } \\
\text { assessment independently. Data- } \\
\text { evaluation criteria regarding } \\
\text { authorship, method of obtaining } \\
\text { and analyzing data, comparability, } \\
\text { and quality are precisely defined. }\end{array}$ \\
\hline
\end{tabular}




\begin{tabular}{|c|c|c|c|}
\hline \multicolumn{4}{|c|}{ Clean } \\
\hline $\begin{array}{l}\text { No awareness that given data } \\
\text { might have to be checked, } \\
\text { cleaned, or normalized. Data is } \\
\text { further processed as is. }\end{array}$ & $\begin{array}{l}\text { Awareness that given data most } \\
\text { often is not perfect. Awareness of } \\
\text { some data quality criteria (e.g., } \\
\text { empty fields, duplicates) and } \\
\text { manual fixing of errors. }\end{array}$ & $\begin{array}{l}\text { Invalid records can be detected } \\
\text { and are removed using programs } \\
\text { that support data cleaning (e.g., } \\
\text { OpenRefine). High awareness of } \\
\text { data quality criteria (e.g., machine } \\
\text { processable, empty fields, } \\
\text { duplicate detection). }\end{array}$ & $\begin{array}{l}\text { Independent ability to remove } \\
\text { invalid records and translating all } \\
\text { the columns to use a set of values } \\
\text { through an automated script. } \\
\text { Ability to combine different } \\
\text { datasets into a single table, remove } \\
\text { duplicate entries, or apply any } \\
\text { number of other normalizations. } \\
\end{array}$ \\
\hline \multicolumn{4}{|c|}{ Analyze } \\
\hline $\begin{array}{l}\text { Bar and pie charts, simple use of } \\
\text { data tables, and basic summaries } \\
\text { of data. }\end{array}$ & $\begin{array}{l}\text { Ability to work with basic } \\
\text { descriptive statistics. Pivot tables } \\
\text { for aggregating information, } \\
\text { histograms, and box plots. }\end{array}$ & $\begin{array}{l}\text { Ability to work with advanced } \\
\text { statistics (e.g., inferential view of } \\
\text { data, linear regression, decision } \\
\text { trees). }\end{array}$ & $\begin{array}{l}\text { Full suite of machine learning } \\
\text { tools (e.g., clustering, forecasting, } \\
\text { boosting, ensemble learning). }\end{array}$ \\
\hline \multicolumn{4}{|c|}{ Visualize } \\
\hline $\begin{array}{l}\text { No awareness of the multiplicity } \\
\text { of how data can be presented. No } \\
\text { understanding of when standard } \\
\text { visualizations are chosen; } \\
\text { decisions based on what looks } \\
\text { best (trial and error). }\end{array}$ & $\begin{array}{l}\text { Ability to find specific outputs in } \\
\text { accordance with information that } \\
\text { needs to be represented (e.g., in } \\
\text { Excel). }\end{array}$ & $\begin{array}{l}\text { Creation of interactive } \\
\text { charts/dashboards. Uncertainties } \\
\text { are always visualized along with } \\
\text { the data. }\end{array}$ & $\begin{array}{l}\text { High awareness of the various } \\
\text { forms in which data can be } \\
\text { presented (written, numerical or } \\
\text { graphic). Sophisticated } \\
\text { visualizations are programmed, } \\
\text { linked, and dynamic dashboards } \\
\text { that anticipate user requests are } \\
\text { designed. }\end{array}$ \\
\hline \multicolumn{4}{|c|}{ Communicate } \\
\hline $\begin{array}{l}\text { Insights from data are not } \\
\text { communicated or put into a } \\
\text { broader context. }\end{array}$ & $\begin{array}{l}\text { Limited ability to find specific } \\
\text { outputs. Simple narrative support } \\
\text { static visualizations/key numbers } \\
\text { (e.g., reporting to funding } \\
\text { partners, newsletters). }\end{array}$ & $\begin{array}{l}\text { Own projects are supported by } \\
\text { interactive visualizations and } \\
\text { more sophisticated narrative in a } \\
\text { broader context (e.g., data } \\
\text { storytelling, conferences, talks, } \\
\text { monthly updates, blog posts). }\end{array}$ & $\begin{array}{l}\text { Ability to synthesize and } \\
\text { communicate in ways suited to the } \\
\text { nature of the data, their purpose, } \\
\text { and the audience (e.g., data } \\
\text { storytelling, data-driven } \\
\text { campaigning, workshops, } \\
\text { conferences, monthly updates, } \\
\text { blog posts, reproducible research). }\end{array}$ \\
\hline \multicolumn{4}{|c|}{ Assess and Interpret } \\
\hline $\begin{array}{l}\text { Data outputs are used at face value } \\
\text { without questioning their } \\
\text { correctness and message. }\end{array}$ & $\begin{array}{l}\text { Growing awareness for critically } \\
\text { assessing data outputs and } \\
\text { interpreting the results. } \\
\text { Insecurities regarding what } \\
\text { exactly to pay attention to. }\end{array}$ & $\begin{array}{l}\text { Data outputs and results are } \\
\text { interpreted confidently and } \\
\text { critically. Evaluation criteria are } \\
\text { internalized. }\end{array}$ & $\begin{array}{l}\text { Data outputs and results are } \\
\text { consistently questioned and } \\
\text { challenged, interpretation extends } \\
\text { the obvious, and information are } \\
\text { successfully translated into } \\
\text { actionable knowledge. } \\
\end{array}$ \\
\hline
\end{tabular}

In contrast, the other person felt that the usability is rather low due to the long text answers in some areas of the questionnaire.

\subsection{Applying the Data Literacy Maturity Model}

The two participants of the model evaluation, from an NGO that is currently involved in data training activities and that used the DLMM, scored a data literacy maturity level of two (see Figure 3). Overall, this means that the evaluated employees are experimenting with the application of data-related topics. This phase describes a state where much about data has already been understood theoretically, but this knowledge cannot be applied in many cases and has to be further trained. To obtain valuable insights on data literacy competencies in an organization, the tool should be used not only by single individuals in an organization but also within entire teams to get a better understanding of the overall situation and make the results more meaningful.
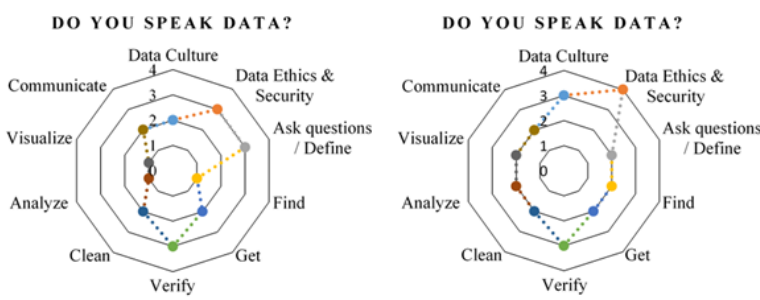

\section{Figure 3. Results of the DLMM self- evaluation}

\subsection{Continuation or Rejection of the Model}

The last step in the procedure model is the rejection or continuation of the model. Reflecting on the evaluation outcome, the model is still considered to be a useful tool to help individuals find out how people handle data and where they still need to be 
trained more intensively on data competencies. According to the collected data, this will help to promote openness on working with, using, and communicating with data and better planning education programs. Critical reactions to the model mainly concerned missing dimensions throughout the development process, as well as a lack of presenting the complexity of data literacy in a maturity model. The missing dimensions were added in accordance with the suggestions by the experts. In addition, the aim of the study was to create a first attempt at representing the topic in a maturity model that allows for future adaptations and only offers option values so far. For this reason, a rejection of the model is not necessary at this point. However, further adaptations need to be acknowledged and will be incorporated iteratively through using the model in real-world application scenarios.

\section{Conclusion}

This study contributes to the general question of how to describe data literacy for individuals in the context of NGOs in a maturity model. With the help of action design research through three iteration phases, the maturity model grew from seven initial dimensions to 11 more detailed dimensions at each phase of the development process. The major research contribution lies in the development of the maturity grid and the translation into an easy-to-use self-evaluation tool that helps to evaluate current data-handling and data-conversion skills and to better prepare for future data practice. This research suggests a description of data literacy based on 11 competencies: (1) data culture, (2) data ethics and security, (3) ask questions and define, (4) find, (5) get, (6) verify, (7) clean, (8) analyze, (9) visualize, (10) communicate, and (11) assess and interpret. These dimensions are described across four competence levels: (1) uncertainty, enlightenment, (3) certainty, and (4) data fluency.

This study set out to explore the definition of data literacy in a maturity model, which represents an original contribution to the research domain. Although the findings of this research suggest that representing data literacy in a maturity model can be a helpful way to foster discussion in organizations, especially regarding the evaluation of current competencies and planning for the future, it was challenged by the fact that it tends to simplify the topic under investigation and cannot represent the multiplicity of organizational contexts. However, it was not within the scope of this paper to offer a "onesize-fits-all" solution but, rather, to offer a proposal of option values as a guideline. Moreover, the paper may encourage discussion of the bigger picture of data literacy competencies and thus make future educational endeavors more scalable and measurable.

Although the research has reached its aim to explore and describe data literacy in a maturity model for NGOs, unavoidable limitations need to be acknowledged. First, the period of time dedicated to this study limits what is revealed, especially regarding the ambitious development process that comprised three iteration phases. This led to the conscious decision to focus the data collection process on the selected cases. As a consequence, the ability to draw generalizations for NGOs is limited, and the model presents itself in a rather generic version that potentially can also be used and investigated further in other domains. Second, the decision to represent data literacy in a maturity model was a new approach that was best investigated with the exploratory character of qualitative research methods such as expert interviews. A main shortcoming of this approach is the subjective influence regarding data collection and the analysis of the results.

Overall, the research sets the stage for further promising research directions around the topic of data literacy. One potential research lead is the exploration of a benchmarking function of the model between different organizations. What are differences between learning organizations and organizations that already have a certain expertise in data-handling and -conversion topics? This could be an exciting way to further refine the model in varying organizational contexts. Moreover, examining the correlations among the different competencies that are described in the DLMM could lead to promising research streams. It would be interesting to learn about the connections among and influence of the different dimensions and which recommendations and insights can be drawn from them. This could be an interesting research focus, as the findings of this study suggest that the big contextual difference between NGOs can have a dramatic impact on the interpretation of data literacy.

\section{References}

[1] Argyris, C. and Schön, D.A. Organizational learning. Addison-Wesley Pub. Co., Reading, Mass., 1978.

[2] Becker, J., Knackstedt, R., and Pöppelbuß, J. Developing Maturity Models for IT Management: A Procedure Model and its Application. Business \& Information Systems Engineering 1, 3 (2009), 213-222. [3] Bhargava, R. and D'Ignazio, C. Designing Tools and Activities for Data Literacy Learners. Workshop on Data Literacy, Webscience, (2015). 
[4] Calzada Prado, J. and Marzal, M.Á. Incorporating Data Literacy into Information Literacy Programs: Core Competencies and Contents. Libri 63, 2 (2013), 123-134. [5] Cambridge Dictionary. Meaning of maturity in the English dictionary. 2016.

http://dictionary.cambridge.org/dictionary/english/maturity. [6] Chall, J.S. Stages of reading development. McGrawHill, New York, 1983.

[7] Chiesa, V., Frattini, F., Lazzarotti, V., and Manzini, R. Designing a performance measurement system for the research activities: A reference framework and an empirical study. Journal of Engineering and Technology

Management 25, 3 (2008), 213-226.

[8] Cosic, R., Shanks, G., and Maynard, S. A business analytics capability framework. Australasian Journal of Information Systems, 19, (2015), S5-S19.

[9] Crosby, P.B. Quality is free: the art of making quality certain. Mentor, New York, 1980.

[10] Data-Pop Alliance. Beyond Data Literacy:

Reinventing Community Engagement and Empowerment in the Age of Data. 2015.

https://atatherapy.files.wordpress.com/2015/10/beyonddata-literacy-2015.pdf.

[11] Datenschule. OKF Datenschule. Datenschule, 2016. https://dev.datenschule.de/.

[12] Deahl, E. Better the Data You Know: Developing Youth Data Literacy in Schools and Informal Learning Environments (Ph.D. Thesis) Massachusetts Institute of Technology. 2014.

[13] Debnath, S., Lee, B., and Tandon, S. Fifty years and going strong: What makes behaviorally anchored rating scales so perennial as an appraisal method? International Journal of Business and Social Science 6, 2 (2015), 16-25. [14] Desouza, K.C. and Smith, K.L. Big Data for Social Innovation (SSIR). Stanford Social Innovation Review, 2014.https://ssir.org/articles/entry/big_data_for_social_inno vation.

[15] Enkel, E., Bell, J., and Hogenkamp, H. Open Innovation Maturity Framework. International Journal of Innovation Management 15, 6 (2011), 1,161-1,189.

[16] Felden, C. Integrating structured and unstructured data in a business-intelligence-system.Language@Internet 3, 5 (2006).

[17] Fraser, P., Moultrie, J., and Gregory, M. The use of maturity models/grids as a tool in assessing product development capability. International Engineering Management Conference (IEMC), IEEE (2002), 244-249.

[18] Fry, B.J. Computational information design. 2004.

[19] Gottschalk, P. Maturity levels for interoperability in digital government. Government Information Quarterly 26, 1 (2009), 75-81.

[20] Gray, J., Bounegru, L., Chambers, L., European Journalism Centre, and Open Knowledge Foundation, eds. The data journalism handbook. O'Reilly Media, Sebastopol, CA, 2012.

[21] Hevner, A., March, S., Park, J., and Ram, S. Design Science in Information Systems Research. MIS Quarterly 28, 1 (2004), 75-105.

[22] Hillson, D.A. Towards a Risk Maturity Model. The International Journal of Project and Business Risk Management 1, 1 (1997), 35-45.
[23] Loch, C.H. and Tapper, U.A.S. Implementing a strategy-driven performance measurement system for an applied research group. Journal of Product Innovation Management 19, 3 (2002), 185-198.

[24] Maier, A., Moultrie, J., and Clarkson, J. Developing Maturity Grids for Assessing Organisational Capabilities: Practitioner Guidance. IEEE Transactions on Engineering Management 59, 1 (2012), 138-159.

[25] McGrath, M.E. and McGrath, M.E., eds. Setting the PACE in product development: A guide to Product And Cycle-time Excellence. Butterworth-Heinemann, Boston, MA, 1996.

[26] Meuser, M. and Nagel, U. Das Experteninterview konzeptionelle Grundlagen und methodische Anlage. In S. Pickel, G. Pickel, H.-J. Lauth and D. Jahn, eds., Methoden der vergleichenden Politik- und Sozialwissenschaft. VS Verlag für Sozialwissenschaften, Wiesbaden, 2009, 465479.

[27] Paulk, N.C. Extreme programming from a CMM perspective. IEEE Software 18, 6 (2001), 19-26.

[28] Pöppelbuß, J. and Röglinger, M. What makes a useful maturity model? A framework of general design principles for maturity models and its demonstration in business process management. Proceedings of the European Conference on Information Systems (ECIS), (2011). [29] Ross, J. Creating a strategic IT architecture competency: learning in stages. MIS Quarterly Executive 2, 1 (2003).

[30] Sein, M., Henfridsson, O., Purao, S., Rossi, M., and Lindgren, R. Action Design Research. MIS Quarterly 35, 1 (2011), 37-56.

[31] Shaw, J. Why "Big Data" Is a Big Deal. Harvard Magazine, 3 (2014), 30-35.

[32] Slater, D. Research Results Part 1: Defining Data Literacy. School of Data, 2016.

http://schoolofdata.org/2016/01/08/research-results-part-1defining-data-literacy/.

[33] Snell, S., Morris, S., and Bohlander, G.W. Managing human resources. Cengage Learning, Boston, MA, USA, 2016.

[34] Süssenguth, F. Die Organisation des digitalen Wandels - Zur Funktion von Digitalisierungssemantiken. In Die Gesellschaft der Daten: über die digitale Transformation der sozialen Ordnung. Transcript, Bielefeld, 2015, 93-121. [35] UN Data Revolution Group. A world that counts mobilising the data revolution for sustainable development. 2014.

[36] UNESCO. The plurality of literacy and its implications for policies and programmes. Paris, 2004. [37] Vallerand, J., Lapalme, J., and Moïse, A. Analysing enterprise architecture maturity models: a learning perspective. Enterprise Information Systems 11, 6 (2017), $859-883$.

[38] Webster, J, Watson, R. Analyzing the Past to Prepare for the Future: Writing a Literature Review. MIS Quarterly 26, 2 (2002), 13-23

[39] Wolff, A., Gooch, D., Cavero Montaner, J.J., Rashid, U., and Kortuem, G. Creating an understanding of data literacy for a data-driven society. The Journal of Community Informatics 12, 3 (2016), 9-26. 